\title{
Mścisława Wartenberga wykładnia metafizyki w perspektywie filozofii Immanuela Kanta
}

Mścisław Wartenberg (1868-1938) to urodzony w wielkopolskim Żninie, wykształcony filozoficznie i matematycznie, autor wielu prac z zakresu epistemologii, etyki i ogólnej teorii bytu, powstałych pod wpływem szeroko zakrojonych badań historyczno-krytycznych. Podejmując studia we Wrocławiu, Lipsku, Tybindze oraz Jenie, a następnie realizując się zawodowo jako pracownik naukowy Uniwersytetu Jagiellońskiego oraz Lwowskiego Uniwersytetu Jana Kazimierza, którego atmosferę intelektualną zagęszcza duch XIX wieku, dokonuje taksacji myśli Immanuela Kanta, tropiąc zarówno zalety, jak i wady jego filozofii, skoncentrowanej zasadniczo wokół problemu metafizyki ${ }^{1}$.

Wartenberg świadomy tradycji metafizycznej i przemian dokonujących się na przestrzeni wieków w jej obszarze, opisuje swoje stanowisko w dziele Obrona metafizyki. Krytyczny wstęp do metafizyki opublikowanym w Kra-

${ }^{1}$ Dowodzą tego liczne publikacje: artykuł Kantowska argumentacja przeciwko idealizmowi z 1905 roku; niemal trzystustronicowe, wynikające z krytycznego przemyślenia, realistyczne dzieło Kants Theorie der Kausalität mit besonderer Berücksichtigung der Grundprinzipien seiner Theorie der Erfahrung. Ein historisch-kritische Untersuchung zur Erkenntnistheorie; metafizyczne Das Problem des Wirkens und die monistische Weltanschauung mit besonderer Beziehung auf Lotze. Eine historisch-kritische Untersuchung zur Metaphysik (1900), Obrona metafizyki. Krytyczny wstęp do metafizyki oraz O kantowskiej krytyce praktycznego rozumu i jej stosunku do krytyki czystego rozumu z 1911 roku. Na temat problemu metafizyki w filozofii Kanta zob. A. Noras, Kant a neokantyzm badeński i marburski, Katowice 2005, s. 17-100. 
kowie w 1902 roku. Prologiem do badawczych analiz założeń przyjętych przez Kanta czyni w tej pracy refleksję nad metafizyczną myślą minionych epok. Przyjmuje, że w dużej mierze zainteresowanie problemem metafizyki, filozofia zawdzięcza Andronikosowi z Rodos (I w. p.n.e.), pełniącemu funkcję naczelnika szkoły młodszych perypatetyków. Scholarcha Lykeionu, analizując zasady nauki Arystotelesowskiej, poddaje zebraną bibliotekę dzieł Stagiryty regule charakterystycznego i powszechnie znanego trójpodziału.

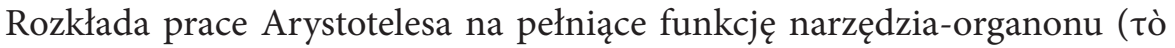

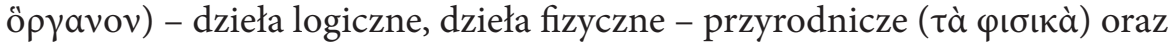
prace podejmujące zagadnienie filozofii pierwszej ( jako nauki o bycie, substancji wszechrzeczy i ostatecznej przyczynie ( $\tau \grave{\alpha}$

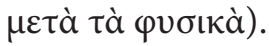

Wartenberg przypomina, że wyrażenie "metafizyka” nabiera nowego sensu wraz z powstaniem komentarzy do pism Arystotelesa popełnionych przez reprezentantów - jak pisze - szkoły nowo-platońskiej (neoplatońskiej), którzy dokonują zamiany pospolitego znaczenia wyrazu metafizyka w znaczenie rzeczowe ${ }^{2}$. Ujęcie rzeczowe, o którym pisze Wartenberg obej-

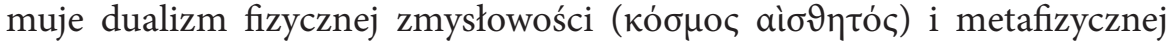

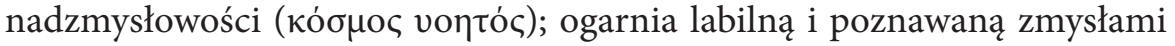
na podstawie wrażeń zmysłowych, sferę zjawiskową oraz stałą, uformowaną w postać zespołu pojęć ogólnych oraz zasad i poznawaną rozumem w procesie czystego myślenia, sferę istoty rzeczy jako sferę bytu prawdziwego. Tak rozumiana metafizyka $\mathrm{w}$ jej nowym, racjonalnym - głoszonym jeszcze w dogmatycznej nauce Christiana Wolffa (1679-1754), przełamanej z czasem krytycznym podejściem Kanta - sposobie obrazowania, jest specyficzną umiejętnością filozoficzną, której przedmiot leży ponad fizyką i poza światem zjawiskowym ${ }^{3}$.

Alternatywą dla kierunków racjonalistycznych broniących tradycyjnego, bipolarnego rozdziału świata na mundus sensibilis i mundus intelligibilis, jest - sugeruje Wartenberg - myśl Davida Hume’a (1711-1776), budującego gmach wiedzy na bazie impresji zmysłowo-reflektywnych i przestrzenno-czasowych stosunków występujących pomiędzy wrażeniami zmysłowymi, a zatem stanowiska uznającego prymarną ważność faktów empirycznych przetwarzanych w obrazy mentalne. Hume jako myśliciel o sceptycznym

${ }^{2}$ Zob. M. Wartenberg, Obrona metafizyki. Krytyczny wstęp do metafizyki, Kraków 1902, s. 10 .

${ }^{3}$ Zob. tamże, s. 10. 
usposobieniu, przenosi akcent z refleksji metafizycznej w obszar empirycznie zabarwionej epistemologii, nazywając metafizykę dziedziną subiektywno-psychologiczną. W ten sposób odrzuca jej znaczenie jako nauki traktującej o istocie bytu.

Ten krótki i wybiórczy opis kształtowania się myśli metafizycznej, służy Wartenbergowi do ukazania Kantowkiego terminus a quo. Filozof twierdzi, że Kant identyfikuje metafizykę z refleksją krytycznopoznawczą, to znaczy odrzuca metafizykę traktującą o nadzmysłowym świecie rzeczy samych w sobie, nadając jej znaczenie krytycznej nauki o możliwym zakresie poznania $^{4}$. Pierwotnie Kant przekonuje: poznawczo dostępna jest nam jedynie sfera zjawiskowa, zatem w celu usystematyzowania tej wiedzy i uzyskania poznawczej pewności i konieczności ludzki umysł wykorzystuje aprioryczne zasady i formy, za pomocą których porządkuje treść wrażeń zmysłowych. Metafizyka nie jest więc nauką zdolną ująć istotę bytu/zjawiska/rzeczy, lecz dziedziną podejmującą rozważania nad apriorycznymi formami i zasadami poznawczymi. Pierwotnie Kant odrzuca metafizykę transcendentną jako naukę o istocie rzeczy, przyjmując metafizykę immanentną jako krytyczną naukę o zasadach i granicach poznania ${ }^{5}$.

Jeszcze przed wykuciem się $\mathrm{w}$ filozoficznym materiale filozofii polskiej trwałego tworu przyjmującego postać projektu obrony metafizyki, w 1899 roku ukazuje się Wartenbergowska praca Kants Theorie der Kausalität mit besonderer Berücksichtigung der Grundprinzipien seiner Theorie der Erfahrung. Ein historisch-kritische Untersuchung zur Erkenntnistheorie, będąca syntetycznie przeprowadzoną analizą oraz krytyką Kantowskiej teorii przyczynowości, dokonaną z perspektywy realizmu gnoseologicznego stanowiska znamiennego dla naukowej postawy Wartenberga. Formuła uznana za tezę wyróżnionej pracy jest próbą eksplikacji faktu nazywającego zasadę przyczynowości sądem syntetycznym a priori; sądem nie czerpiącym swego uzasadnienia $\mathrm{z}$ doświadczenia; formuła ta również nigdy przez doświadczenie nie będzie mogła zostać obalona, a jej wyjaśnienie znajduje Kant w transcendentalnej dedukcji kategorii przyczynowości ${ }^{6}$.

Kantowską causa principio tłumaczy zdanie ujęte prawidłem: każda zmiana ma swoją przyczynę, która dotyczy wszelkich przedmiotów możliwego doświadczenia i przyjmuje postać członu przyczynowej relacji. Kant

\footnotetext{
${ }^{4}$ Zob. tamże, s. 13.

${ }^{5}$ Zob. tamże.

${ }^{6}$ Por. K. Ajdukiewicz, Mścisław Wartenberg, „Ruch Filozoficzny” 1938/14, s. 178.
} 
ma świadomość istnienia określonego porządku zjawisk, dyktowanego regułami czystych kategorii intelektu. Kategorie zastosowane do zjawisk są formami intelektualnymi, uzmysłowionymi (sensifiziert) działaniem symbolu - transcendentalnego schematu jako monogramu czystej wyobraźni a priori ${ }^{7}$. Wprowadzenie schematu transcendentalnego jako swoistego pośrednika między czystym pojęciem a zmysłową treścią, jest ustępstwem aprioryzmu na rzecz empiryzmu. Kant ukierunkowuje przyczynowość jako czystą kategorię intelektu na zjawisko wtedy i tylko wtedy, gdy następujące po sobie zjawiska układają się już według określonej reguły ${ }^{8}$. Zjawiska ujmowane w stosunkach przyczynowych podlegają obiektywnemu odniesieniu następstwa czasowego. Zgodnie z przesłaniem Kanta, dopóki do zjawisk nie zastosujemy kategorii przyczynowości, mamy do czynienia jedynie z subiektywnym następstwem naszych spostrzeżeń, które nie są równoznaczne z obiektywnym następstwem ujmowanych zjawisk ${ }^{9}$. Wartenberg zaprzecza temu twierdzeniu, nazywając umysł narzędziem, które samo w sobie dysponuje możliwością rozróżniania obiektywnego i subiektywnego następstwa zjawisk na podstawie modi, w jakim mu się one przedstawiają. W związku z tym nie jest prawdą, że poznający podmiot dochodzi „do spostrzeżenia obiektywnego następstwa zjawisk dopiero przez to, że do nich zastosuje kategorię przyczynowości"10. Kierując się tezami transcendentalnej dedukcji Kanta, Wartenberg stwierdza, że rozum jako narzędzie poznawcze używa zasady przyczynowości, która może być stosowana do porządkowania zjawisk, napotykając je w formie ułożonej według obiektywnego następstwa czasowego, uzyskanego już na poziomie doznań; tym samym zasada przyczynowości nie posiada znamion zasady konstytutywnej, lecz ma wyłącznie regulatywny - nieapodyktyczny - charakter, co znaczy że jest - nieskoncentrowaną na doświadczeniu - zasadą porządkującą, której zadanie polega wyłącznie na wyszukiwaniu związków przyczynowych między zjawiskami. Kant jednak, budując gmach swej filozofii, nadaje przyczynowości właściwej dla świadomości empirycznej charakter regulatywny, natomiast świadomość transcendentalną pragnie uczynić - niestety próżnym według Wartenberga wysiłkiem - narzędziem zarządzającym przyczynowością konstytutywną.

\footnotetext{
${ }^{7}$ I. Kant, Krytyka czystego rozumu, t. 1, przeł. R. Ingarden, Warszawa 1957, s. 371.

${ }^{8}$ Por. S. Borzym, Panorama polskiej myśli filozoficznej, Warszawa 1993, s. 95-96.

${ }^{9}$ K. Ajdukiewicz, Mścisław Wartenberg..., s. 178.

${ }^{10}$ Tamże, s. 178.
} 
Wady Kantowskiej pracy nad przyczynowością konstytutywną działają osłabiająco na cały system aprioryzmu, umacniając rolę doświadczenia formującego się niezależnie od funkcji intelektu. Na tej podstawie Wartenberg nazywa Kantowską kategorię przyczynowości odniesioną, nie do transcendentalnej sfery rzeczy samych w sobie, lecz do immanentnego obszaru zjawisk. Zgodnie z tym, co w swojej filozofii twierdzi Kant: to rzecz, oddziałując, pobudza zmysły, w wyniku czego w relacji kauzalnej wyodrębniają się wrażenia jako przyczyny Ding an sich. Rzecz świata poza świadomością, czyli świata zewnętrznego, wywiera wpływ na świat Bewusstsein - świat świadomości.

W ostatecznym rozwiązaniu kwestii przyczynowości Wartenberg oczekuje od Kanta odpowiedzi na następujące pytania: do jakiej sfery - transcendentnej czy immanentnej - stosuje się przyczynowość? Czy rzecz sama w sobie jest zdolna pobudzać zmysły? Jeśli w teoretycznej filozofii Kanta odpowiedź na tak postawione pytanie, jest twierdząca tzn. rzecz sama w sobie pobudza zmysły, to przyczynowość będzie miała charakter transcendentny; z kolei, jeśli Kant wyłożoną przez siebie nauką udziela odpowiedzi przeczącej, to przyczynowość będzie miała znaczenie immanentne i jako taka, stosować się będzie wyłącznie do zjawisk. Ostatecznie Kant nie znalazł rozwiązania problemu przyczynowości wikłając się w różnego typu sprzeczności.

W tym miejscu należy dodać, że na kartach Kants Theorie, Wartenberg prezentuje się jako zwolennik realistycznej formy poznania, odmawiając zasadzie przyczynowości znaczenia koniecznego i przyjmując za Christophem Sigwartem stanowisko, w myśl którego przyczynowość jest „postulatem myślenia dążącego do poznania rzeczywistości”"11. Jest nietranscendentalnym, racjonalnym, apriorycznym i psychologiczno-logicznym dodatkiem do doświadczenia jako syntetyzującej funkcji myślenia ${ }^{12}$.

Stanisław Borzym zauważa, że znamienny dla Wartenberga, krytyczny realizm teoriopoznawczy, czyni z przyczynowości „pojęcie o implikacjach ontologicznych, na czym Wartenbergowi zależy ze względu na zamierzony program »obrony metafizyki «"13. Program wprowadzany w czyn pod wpływem Kantowskiego, dualistycznego ujęcia rzeczywistości jako fenomenalnej (immanentnej) i noumenalnej (transcendentnej). W takim ujęciu przyczynowość jest realnym stosunkiem występującym między substancjami,

\footnotetext{
${ }^{11}$ S. Borzym, Panorama polskiej myśli filozoficznej..., s. 99.

${ }^{12}$ Por. tamże, s. 96-99.

${ }^{13}$ Por. tamże, s. 101.
} 
w ramach którego substancje te oddziałują wzajemnie na siebie, pobudzając się do przekształcania swych stanów; z kolei substancja jako taka, jest samoistnym podkładem pewnych właściwości i stanów istniejących w rzeczy. W ten sposób Wartenbergowska interpretacja zasady przyczynowości Kanta, traktuje nie tylko o regularnym następstwie zjawisk, ale wprowadza także konieczny element czynności, działania, siły, wreszcie substancji jako realnego podmiotu działającej siły ${ }^{14}$.

$\mathrm{Na}$ tej podstawie Wartenberg wnioskuje, że Kantowskie określenie substancji i przyczynowości, nie spełnia warunków Kantowskiego fenomenalizmu. Zjawisko wyraża jedynie określoną właściwość i stan, nie przedstawiając sobą żadnego substratu. Jako substantia phaenomenon nie jest prawdziwą realną substancją, lecz zwyczajną sprzecznością natury contradictio in adjecto. Tym samym zjawisko, które nam się przedstawia jest jedynie nośnikiem wyobrażonych własności oraz stanów rzeczy. Tymczasem według argumentacji Wartenberga - właściwie oddziaływać może jedynie substancja jako realistycznie pojęta racja bytu ${ }^{15}$.

Chęć zachowania realistycznego znaczenia kategorii - czystych pojęć intelektu jako warunków koniecznych poznawania i określania przedmiotów - każe Wartenbergowi odrzucić ścisły fenomenalizm Kanta. Polski filozof wysuwa postulat uwzględnienia wartości i ważności kategorii w określaniu transcendentnego bytu rzeczy samych w sobie, co dowodzić ma słuszności zasady traktującej o „możliwości przekraczania granic doświadczenia w celach poznawczych i określania za pomocą kategorii własności samoistnego bytu" 16 .

Nieczytelność Kantowskiego stanowiska - jak podkreśla Wartenberg polega na akcentowaniu faktu niepoznawalności i niemożności pozytywnego określenia sfery transcendentnej oraz zastosowaniu do tej sfery kategorii bytu, przez uwzględnienie faktu istnienia bytu rzeczy samych w sobie. Kant daje do zrozumienia, że rzeczy same w sobie istnieją jednocześnie jednak podkreśla niemożliwość ich poznania, ze względu na brak odpowiednich form poznawczych. Niespójność Kantowskiego stanowiska polega na tym, iż wydaje on na temat rzeczy samej w sobie sąd egzystencjalny, wyrażający się w zastosowaniu do niej kategorii bytu-istnienia, która zgodnie z założeniami jego systemu powinna odnosić się wyłącznie do zjawisk.

\footnotetext{
${ }^{14}$ Por. M. Wartenberg, Obrona metafizyki..., s. 104.

${ }_{15}$ Zob. tamże, s. 105.

${ }^{16}$ Zob. tamże, s. 106.
} 
Kant twierdzi, że "musimy przyjąć istnienie rzeczy samych w sobie, jako konieczny komplement zjawisk, ponieważ pojęcie zjawiska straciłoby wszelkie zrozumiałe znaczenie, gdyby nie istniały rzeczy, które w zjawiskach się objawiają" ${ }^{17}$. Decydując się na wydanie pozytywnego, egzystencjalnego sądu o rzeczy samej w sobie, która - choć jest niepoznawalna - istnieje, Kant przekracza granicę immanentnej sfery zjawiskowo-fenomenalnej, kojarzoną przezeń $\mathrm{z}$ systemem zasad utrzymywanych w szrankach możliwego doświadczenia ${ }^{18}$; sprzeniewierza się swoim teoriopoznawczym zasadom przyjętym w punkcie wyjścia, wkraczając w obszar transcendentnej rzeczy samej w sobie. Na tej podstawie prawomocne byłoby - wedle Wartenberga - nazwanie Kanta metafizykiem transcendentnym.

Swoje stanowisko Wartenberg potwierdza głębszą analizą myśli Kanta. Filozoficzna teoria królewieckiego myśliciela, kategorie jako czyste pojęcia intelektu oraz czas i przestrzeń jako czyste formy naoczności odnosi wyłącznie do zjawisk, nigdy do rzeczy samej w sobie. Przyjęty punkt widzenia prowokuje pytania: skąd Kant czerpie wiedzę o niepoznawalnej sferze transcendentnej?; skąd wie, co się odnosi, a co nie odnosi do rzeczy samych w sobie, skoro byt samoistny (rzecz samą w sobie) nazywa niepoznawalnym? Niepoznawalność jako cecha, jest według Wartenberga tożsama z absolutną niemożnością wypowiedzenia jakiegokolwiek sądu o tym, co niepoznawalne. Każdy sąd pozytywny-twierdzący (deklarujący czym coś jest; jakich własności jest nośnikiem dana rzecz) lub negatywny-przeczący (deklarujący czym coś nie jest; jakich własności nie jest nośnikiem dana rzecz) jest już twierdzeniem o tym, co opisywane. A zatem fakt wypowiedzenia przez Kanta sądu, który uwzględnia różnicę posiadanych własności występujących pomiędzy zjawiskiem a bytem transcendentnym - rzeczą samą w sobie, jest już uznaniem tej rzeczy (to znaczy rzeczy samej w sobie) za poznawalną. Na tej podstawie Wartenberg utwierdza się w przekonaniu o Kantowskiej niekonsekwencji systemowych założeń i po raz kolejny wnioskuje, że Kant przekracza sferę zjawiskową, do której wcześniej próbował ograniczyć poznanie, wykracza poza przyjęty punkt wyjścia, stając się z dużym prawdopodobieństwem bezwiednie - metafizykiem transcendentnym $^{19}$. Świadczy o tym posłużenie się „czynnikiem transcendentnym jako zasadą w celu wytłumaczenia powstania wrażeń zmysłowych, tworzących

\footnotetext{
17 Tamże.

${ }^{18}$ Zob. I. Kant, Krytyka czystego rozumu, przeł. R. Ingarden, Kęty 2001, s. 292.

${ }^{19}$ Por. M. Wartenberg, Obrona metafizyki..., s. 106-107.
} 
materię zjawisk, bez której aprioryczne formy poznawcze byłyby próżnymi formami bez treści i nie posiadałyby jako takie żadnego przedmiotowego znaczenia" ${ }^{20}$.

Chociaż Kant zapewnia, że nasze poznanie zamyka się w granicach doświadczenia (sfery zjawiskowej), nie jest w stanie sprostać zadaniu obrony swojej fenomenalistycznej (immanentnej) teorii poznania, wykraczając ponad tę teorię wskazaniem na środek poznawczy służący pozytywnemu określeniu natury samoistnego bytu, właściwego sferze transcendentnej. Kant nie stawia realnej granicy między - pozostającą w dziedzinie doświadczenia - sferą immanentną i - wybiegającą poza doświadczenie - sferą transcendentną, czyniąc obie elementami realno-przyczynowego stosunku. Dlatego Wartenberg kojarzy obie sfery ze sobą, pisząc: „rzeczy same w sobie są przyczynami wrażeń zmysłowych - twierdzenia tego nie można w żaden sposób uniknąć, chcąc wytłumaczyć ich powstanie (tj. powstanie wrażeń zmysłowych). Wyrażając swoje zdanie, Kant określa pozytywnie byt samoistny za pomocą kategorii przyczynowości i wprowadza ją jako formę realną do sfery pozazjawiskowej w zupełnym przeciwieństwie do zasad swej fenomenalistycznej teorii poznania" ${ }^{21}$. Autor Krytyki czystego rozumu niesłusznie zatem sądzi, iż fenomenalizm wystarczy wesprzeć dynamiczną koncepcją materii jako złożonej z punktualnych „środowisk sił atrakcyjnych i repulsyjnych"22, które - poprzez wzajemne przyciąganie i odpychanie - ustanawiają rozciągłość, wiodącą cechą materialności. Wartenberg widzi w Kantowskim stanowisku metafizyczną teorię zjawisk materialnych. Neguje znaczenie dynamicznych i oddziałujących na siebie środowisk sił, wkładając w ich miejsce samoistne substancje obdarzone oddziałującymi na siebie siłami. Uważa, że Kant przeciwstawiając się poglądom mechanicznym, zawiązuje metafizyczną teorię zjawisk materialnych; sprowadza zjawisko materialne do pozazjawiskowej przyczyny i po raz kolejny sięga sfery bytu transcendentnego przekraczając swoją fenomenalistyczną teorię poznania. Zgłębia problematykę na temat tego, co wykracza poza sferę fenomenalną, wchodzi w analizy metafizyczne, przyznając sobie wiedzę o tym, co w swojej fenomenalistycznej teorii poznania uznaje wcześniej za całkowicie niepoznawalne ${ }^{23}$. Warto $\mathrm{w}$ tym miejscu wspomnieć, że Wartenberg,

\footnotetext{
${ }^{20}$ Por. tamże, s. $107-108$.

${ }^{21}$ Tamże, s. 110.

22 Tamże, s. 112.

${ }^{23}$ Zob. tamże, s. 112-113.
} 
prowadząc swoje wywody na temat Kantowskiej metafizyki, ma na myśli metafizykę transcendentną i patrząc z jej perspektywy, pisze: „Wobec tych faktów trudno naprawdę zrozumieć, jakim prawem nowo-kantyści wciąż jeszcze twierdzą, że Kant raz na zawsze ograniczył poznanie nasze do fenomenalnego zakresu doświadczenia i wykazał przekonująco niemożebność transcendentnej metafizyki. Przekonaliśmy się, że o tym żadnej mowy być nie może"24.

Spór z Kantem obejmuje głównie tematykę metafizyczną. W Prolegomenach Kant pisze, że źródła metafizycznego poznania nie mogą być empiryczne; nie mogą pochodzić $\mathrm{z}$ doświadczenia, więc podstawą tego pozazjawiskowego poznania nie może być ani doświadczenie zewnętrzne - właściwe fizyce, ani doświadczenie wewnętrzne - reprezentatywne dla psychologii empirycznej; definicję metafizyki zawiera w słowach: „co się tyczy źródeł poznania metafizycznego, to już w jego pojęciu zawarte jest to, że nie mogą one być empiryczne. Jego pryncypia zatem nigdy nie mogą być wzięte z doświadczenia, albowiem poznanie to ma być nie fizyczne, lecz metafizyczne, tj. ma sytuować się poza doświadczeniem [...]. To poznanie a priori, czyli poznanie wypływające z czystego intelektu oraz czystego rozumu"25. Przyjmuje zatem, że dyscyplina ta jako nauka a priori, powinna badać i może badać tylko to, co znajduje się poza granicami doświadczenia.

Tymczasem Wartenberg, udzielając głosu poparcia Kantowskiemu założeniu o przekraczalności granic doświadczenia przez metafizykę, neguje jej możliwość bycia dyscypliną w pełni niezależną od doświadczenia; uważa, że proces przekraczania granic doświadczenia przez metafizykę nie jest tożsamy z jej - proponowaną przez Kanta - pełną niezależnością od doświadczenia. Według Wartenberga można przekraczać granice doświadczenia tylko z należytym uwzględnieniem empirycznych faktów i jedynie na ich podstawie ${ }^{26}$. Metafizyk pragnący dotrzeć do istoty zjawiska, wykracza poza granice doświadczenia, co nie odróżnia jego postępowania od zachowań właściwych przedstawicielowi nauk szczegółowych, których przedmiotem jest rzeczywistość fizyczna, te bowiem także bazują na teoriach przekraczających granice możliwego doświadczenia. W czasach Wartenberga taką

\footnotetext{
${ }^{24}$ Por. tamże, s. 113.

${ }^{25}$ I. Kant, Prolegomena do wszelkiej przyszłej metafizyki, która będzie mogła wystąić jako nauka, przeł. A. Banaszkiewicz, Kraków 2005, s. 19-20.

${ }^{26}$ Zob. M. Wartenberg, Obrona metafizyki..., s. 119. Zob. S. Mazierski, Koncepcja metafizyki hipotetycznej u M. Wartenberga. „Collectanea Theologica. Societatis Theologorum Polonae Cura Edita” XXIV, Varsaviae 1953, s. 77.
} 
koncepcją jest przyrodnicza teoria atomistyczna, którą pojmuje się jako koncept wykraczający poza granice doświadczenia, chociaż niebędący niezależnym od doświadczenia poznaniem a priori. U źródeł tej teorii leży zaobserwowane przez badaczy materialno-fizyczne zjawisko, fakt empiryczny, natura i wniosek, a nie próżne dywagacje wysnute bezpośrednio z czystego rozumu ujętego $\mathrm{w}$ formie szczelnie zamkniętego naczynia. Na tej podstawie polski filozof stawia Kantowi zarzut mieszania pojęć. Fundamentalną wadą Kantowskiego systemu Wartenberg obwołuje bezpodstawne uznanie, że wszystko to, co przekracza empiryczny fakt, jest poznaniem apriorycznym z czystego rozumu. Kant daje się uwieść - nieaktualnej, bo nieuwzględniającej doświadczenia - metafizyce, rozpływającej się w apriorycznych konstrukcjach umysłu; metafizyce wywodzącej się z istoty czystego rozumu, podporządkowanej dyktatowi dogmatycznych racjonalistów ${ }^{27}$.

Mankamentem Kantowskiej konstrukcji filozoficznej jest - twierdzi Wartenberg - niewystarczająco wyeksponowana rola doświadczenia, przy jednoczesnym mocnym akcentowaniu aprioryzmu. Dlatego w swoich badaniach Wartenberg wytacza argument, że metafizyka jako umiejętność realna nie może być nauką rozwijającą się wyłącznie w wymiarze a priori. O ile zagadnienia metafizyczne obejmują sferę aprioryczną, o tyle „świat rzeczywisty dany nam jest bezpośrednio i pierwotnie w formie zjawisk jako faktów doświadczenia; zjawisk, w których objawia się i przedstawia naszej świadomości to, co rzeczywiście istnieje" ${ }^{28}$. Swiaty te łączą się. Z tego powodu wszelka refleksja metafizyczna wynika z doświadczenia, gdyż metafizyczne pytania o naturę czasu i przestrzeni, o znaczenie materii oraz duszy, także kwestii eschatologicznych, dotyczących Boga, nie są elementami niezależnej kreacji naszego umysłu, lecz są tym, co jest rzeczywistym bytem; bytem danym poznającemu $\mathrm{w}$ doświadczeniu. Natomiast doświadczenie jest jedynym możliwym punktem wyjścia badań metafizyki i początkiem metafizycznych zagadnieńn ${ }^{29}$.

Doświadczenie jest naturalnym początkiem metafizycznych problemów, jednak w ciągu postępu procesu poznawczego, problemy te wychodzą poza granice doświadczenia, co nie zmienia faktu, że metafizyczny proces poznawania dokonuje się przez fakty doświadczenia, a więc na podstawie doświadczenia. Kant natomiast jako zwolennik racjonalistycznej teorii po-

\footnotetext{
${ }^{27}$ Zob. M. Wartenberg, Obrona metafizyki..., s. 120-121.

${ }^{28}$ Tamże, s. 124.

${ }^{29}$ Por. tamże.
} 
znania za cechę metafizyki niesłusznie uznaje niezależną od doświadczenia metodę postępowania, zasklepiając się w „obrębie czystego rozumu. Wprzęga się w czyste, aprioryczne pojęcia, w próżne formy bez konkretnej treści [...], żąda, aby metafizyk wymyślał a priori i konstruował swoje zagadnienia z próżnych form czystego rozumu" ${ }^{30}$. Tymczasem żaden przedmiot realny nie może być - deklaruje Wartenberg - wytworem powstałym pierwotnie $\mathrm{w}$ umyśle, gdyż nawet jeśli umysł bierze udział w jego projektowaniu, to dzieje się to na skutek zjawisk, narzucających się umysłowi w formie wrażeń zmysłowych. „Przedmiot realny - rzeczywistość, nie jest więc wytworem naszego umysłu, jak przedmiot idealny poznania matematycznego, lecz oznacza coś, narzucającego się umysłowi w formie faktu"31.

W przekonaniu Wartenberga wątpliwą tezę zawiera w sobie również Kantowski postulat wyniesienia poznania metafizycznego do rangi poznania o apodyktycznej pewności (apodiktische Gewissheit), a więc poznania zachowującego cechy: konieczności i powszechnej ważności, które czynią teorię poznania ciasną i jednostronną. Warunki wiedzy apodyktycznej spełnia tylko i wyłącznie - konstruowane na bazie apriorycznych prawideł poznanie rozumowe i sądy nauk czysto formalnych, takich jak matematyka i logika ${ }^{32}$. Kant uznaje, że aby metafizyka spełniała warunek naukowości, musi konstruować sądy apodyktycznie pewne, które zdolna jest czerpać wyłącznie z czystego rozumu, czym ma potwierdzać również swój aprioryczny charakter. Takie nazywanie metafizyki nauką aprioryczną graniczy z nadaniem umysłowi zdolności poznawania tylko takich przedmiotów, które są jego własnym wytworem; innymi słowy są przedmiotem, który umysł wcześniej skonstruował za pomocą apriorycznych form poznawczych. Tak działający umysł/intelekt konstruuje zjawiska jako przedmioty doświadczenia, złożone $\mathrm{z}$ aposteriorycznych wrażeń zmysłowych oraz apriorycznych form wyobrażania i rozsądku; jako taki „nie jest on zdolny do wytworzenia tego, "co nie jest zjawiskiem w obrębie świadomości, a więc transcendentnego samoistnego bytu"”33.

Wartenberg potwierdza Kantowską sugestię, w myśl której znaczenie konieczności i powszechnej ważności przysługuje jedynie naukom formalnym: matematyce i logice, $\mathrm{z}$ drugiej jednak strony autor Obrony metafizyki

\footnotetext{
${ }^{30}$ Tamże, s. 125.

${ }^{31}$ Tamże, s. 133.

${ }^{32}$ S. Mazierski, Koncepcja metafizyki hipotetycznej u M. Wartenberga..., s. 81. Zob. M. Wartenberg, Obrona metafizyki..., s. 117.

${ }^{33}$ S. Mazierski, Koncepcja metafizyki hipotetycznej u M. Wartenberga..., s. 78.
} 
konfirmuje pogląd, w myśl którego nauki realne nie posiadają statusu nauk koniecznych i powszechnie ważnych, a mimo to nikt nie odmawia im naukowości. W ten sposób myśliciel daje do zrozumienia, że nauki realne, podobnie jak metafizyka, są polem spornych kwestii, z których żadna nie została w pełni rozstrzygnięta; naukowe treści są pełne dylematów; każdą $\mathrm{z}$ nauk krępują tematy dyskusyjne i żadna nauka nie jest wolna od spornych kwestii ${ }^{34}$. To nie oznacza, że w naukach szczegółowych oraz metafizyce nie zachodzi progres i nie poszerza się dotychczasowy horyzont widzenia problemów. W obu sferach mamy do czynienia z postępem, który możemy obserwować przez - wydawane wciąż na świat - nowe owoce przyrodoznawczej i metafizycznej refleksji; różne, wielostronne, nieznane dotąd formy oraz sposoby ujmowania, rozpatrywania i opisywania przyrodoznawczych oraz metafizycznych zagadnieńn ${ }^{35}$.

Stanisław Mazierski, jeden z komentatorów myśli wielkopolskiego filozofa, decydując się na wyjaśniający opis stanowiska Wartenberga w „Collectanea Theologica” z 1953 roku, pisze: „Gdybyśmy zaprzeczyli wartości naukowej poznania metafizycznego, musielibyśmy wyłączyć z systemu nauk te wszystkie działy wiedzy ludzkiej, które posługują się hipotezami i teoriami. A jeśli tego rodzaju zarzutu nie czynimy innym naukom realnym, to nie jesteśmy uprawnieni do eliminowania metafizyki z systemu nauk, bo i ona jest nauką o rzeczywistości, posługującą się hipotezami” ${ }^{36}, \mathrm{z}$ tą jednak różnicą, że hipoteza metafizyczna nie jest empirycznie sprawdzalną hipotezą nauk szczegółowych, lecz postępowaniem wykorzystującym dowód apagogiczny jako argument reductio ad absurdum ${ }^{37}$. Akceptacja presumpcji metafizycznej jest zgodą na niepewność, jest akceptacją rozstrzygnięć połowicznych, przybliżonych, względnych, umiarkowanych, pośrednich i zakładających zmianę.

Wartenberg, uznając „potrzebę logicznej niesprzeczności systemu oraz moc argumentu przez sprowadzenie zdania przeciwnego do niedorzeczności”38, domaga się wykazania niezgodności pomiędzy zdaniem przeciwnym z założeniem oraz przeciwnym z doświadczeniem. Co zatem łączy tak po-

\footnotetext{
${ }^{34}$ Por. M. Wartenberg, Obrona metafizyki..., s. 149.

${ }^{35}$ Tamże, s. 151.

${ }^{36}$ S. Mazierski, Koncepcja metafizyki hipotetycznej u M. Wartenberga..., s. 83. Zob. też przypisy, tamże.

${ }^{37}$ S. Mazierski, Koncepcja metafizyki hipotetycznej u M. Wartenberga..., s. 102.

${ }^{38}$ B. Dembowski, Spór o metafizykę. Główne poglądy na metafizykę w Polsce na przełomie XIX i XX w. Warszawa 1969, s. 113.
} 
stępującego reprezentanta metafizyki z przedstawicielem nauk szczegółowych? Przedstawiciel nauk szczegółowych, pragnąc racjonalnie wytłumaczyć dane zjawisko, tworzy hipotezy i rozwija teorie; przekracza granice doświadczenia i bazuje na prawdopodobieństwie. W związku z tym, żadna teoria $\mathrm{z}$ dziedziny nauk szczegółowych nie ma charakteru apodyktycznego i w tym braku apodyktyczności ujawnia się jej pokrewieństwo z - również pozbawionymi ostatecznych poznawczo znamion - sądami metafizycznymi. Niezależnie bowiem z jakiej perspektywy spoglądamy - nauk szczegółowych czy metafizyki - jeśli przekraczamy granice doświadczenia, to wchodzimy w obszar hipotez, których pewność jest jedynie prawdopodobna ${ }^{39}$. Rozpatrując jakikolwiek przedmiot i odniesioną do niego hipotezę, należy wykluczyć możliwość absolutnego zracjonalizowania owego przedmiotu. Każda hipoteza jest jedynie prawdopodobna - możliwa, ale nie konieczna; to znaczy że, nasz rozum nie jest w stanie jej w pełni zracjonalizować, zawsze bowiem pozostaje jakaś irracjonalna reszta ${ }^{40}$.

$\mathrm{Z}$ tego powodu Wartenberg podważa Kantowski model rozumienia metafizyki, odrzucając jej aprioryczny charakter wsparty przesłanką wyjętą wprost z Krytyki czystego rozumu; tezą, w myśl której wszelkie nasze poznanie zaczyna się wraz z doświadczeniem, dlatego również metafizyka nie może być nauką a priori. Świadczy o tym zarówno sposób, w jaki dany jest nam świat rzeczywisty, który odbieramy zarówno jako fakt doświadczenia, jak i założenie, w myśl którego wszelkie aprioryczne formy i zasady nabywają swojego przedmiotowego znaczenia tylko jako zjawiska. Każdy byt świata rzeczywistego jest nam dany w formie zjawiska, zatem aby poznać jego istotę, należy zbadać odpowiadający temu zjawisku fakt doświadczenia: im głębsze będzie poznanie zjawiska, tym większa będzie szansa na poznanie jego istoty.

O ile fizykowi badającemu teorie atomistyczne nie można narzucić, by bronił stawianych przez siebie hipotez niezależnie od świata materialnego i jego zjawisk, o tyle metafizykowi nie sposób narzucić, by swoje metafizyczne rozstrzygnięcia ustalał niezależnie od doświadczenia. Niepoparte doświadczeniem konstrukcje myślowe są - zdaniem Wartenberga - jedynie fikcją umysłu. Wobec tego, aby metafizyka bazująca na myślowych konstrukcjach i stanowiące tę metafizykę pojęcia miały swoją ważność, muszą wypływać z doświadczenia; innymi słowy, doświadczenie musi stanowić

\footnotetext{
${ }^{39}$ Zob. M. Wartenberg, Obrona metafizyki..., s. 136.

${ }^{40}$ Tamże, s.156.
} 
źródłowy moment każdej metafizycznej konstrukcji myślowej, potwierdzając przekonanie, że pojęcie metafizyczne, czerpiąc z doświadczenia, nie ma znamion czysto apriorycznych ${ }^{41}$.

Przypisanie zasadom czystego przyrodoznawstwa znamion tego, co apodyktycznie pewne odbija się zarówno na Kantowskim fenomenalizmie, jak i na jego krytyce spekulatywnej metafizyki. W konsekwencji Wartenberg jest przekonany, że jedynie uznanie zasad czystego przyrodoznawstwa za hipotezy otworzy drzwi drogi „naukowego poznania sfery rzeczy samych w sobie" ${ }^{\prime 2}$. Głosząc wbrew nauce Kanta postulat poznawalności Ding an sich, Wartenberg uznaje niemożliwość apriorycznej metafizyki racjonalistów; jednocześnie - przekonany o możliwości naukowego uprawiania metafizyki - utrzymuje, że wszelkie problemy zradza Kantowski dualizm immanentnego zjawiska i transcendentnego bytu, nie złączony żadnym realnym wiązaniem. Wartenberg podważa wartość metafizyki racjonalnej jako dziedziny traktującej o wymykającej się doświadczeniu, sferze transcendentnej. Inaczej rzecz ma się z opierającą swoje hipotezy na doświadczeniu, metafizyką empiryczną.

Hipotezy przyjmowane $w$ ramach metafizyki empirycznej mają ten sam status, co hipotezy nauk szczegółowych: naukowo przyjęty postulat nie jest opartą na domniemaniu fikcją, lecz analizowanym przez ludzki umysł „rzeczowym twierdzeniem zdającym sprawę $\mathrm{z}$ istoty rzeczywistości”43. Wartenberg, konfrontując metodologię metafizyki i nauk realnych, przyjmuje, że sama metafizyka jest nauką o rzeczywistości, gdyż fakt eksplikacji zjawiska poprzez wykorzystywanie przez nauki realne hipotez, zaświadcza o koniecznym warunku posługiwania się nimi przez metafizykę. Metafizyka w znaczeniu, jaki nadaje jej Wartenberg (metafizyka empiryczna), jest nauką trzeźwego sądu, uznającą istnienie rzeczywistości niezależnej od umysłu; jest dziedziną, która pragnąc dotrzeć do istotnych elementów bytu, wydaje sądy niepewne - hipotezy. Dlatego metafizyka ta jest w przekonaniu Wartenberga „nauką realną, docierającą do istotnych elementów bytu [a zarazem - A. M.] systemem sądów hipotetycznych" ${ }^{44}$. Jako taka zyskuje miano metafizyki hipotetycznej.

\footnotetext{
${ }^{41}$ S. Mazierski, Koncepcja metafizyki hipotetycznej u M. Wartenberga..., s. 80.

${ }^{42}$ K. Ajdukiewicz, Mścisław Wartenberg..., s. 181.

${ }^{43}$ Tamże, s. 182.

${ }^{44}$ S. Mazierski, Koncepcja metafizyki hipotetycznej u M. Wartenberga..., s. 75.
} 
Zarówno badacz metafizyki, jak i przedstawiciel nauk szczegółowych podejmują wysiłek poznania, wierząc, że formy poznawcze ich umysłu mają przedmiotowe znaczenie. Poznający metafizyk i poznający przyrodoznawca, to podmioty zdolne do krytycyzmu i logicznej rozwagi w wydawaniu sądów, skłonne do zapytywania o prawdę w jej obiektywnym sensie. To nie umniejsza faktu, że każde „poznanie odnoszące się do rzeczywistości, posiada granice; [racje istnienia granic poznania - A. M.] przyzna chętnie każdy nieuprzedzony teoretyk poznania. Byłoby jednak próżnym usiłowaniem, chcieć określać te granice a priori, przed rozpoczęciem badań metafizycznych i oznaczać je raz na zawsze pretensją do absolutnego znaczenia"45.

Jedynie analizy metafizyczne w swym progresywnym procesie rozwoju pozwolą wyznaczyć horyzont wiedzy o rzeczywistym bycie, jak również uświadomić sobie naszą niewiedzę; stanąć przed granicą poznania, której nasz umysł - pragnąc uchronić się przed popadnięciem w subiektywną poezją myśli - nie może przekroczyćc ${ }^{46}$.

Broniąc metafizyki, Wartenberg podważa także słuszność założeń Kantowskiej nauki o antynomiach, pomawiając Królewieckiego myśliciela o brak dostatecznego jej uzasadnienia. Wykorzystując rozprawę autorstwa Franza Erhardta Kritik der Kantischen Antinomienlehre, zarzuca teorii Kanta sztuczność, pozorność, konieczność wyłudzania zasad i sofizmatyzm; jednocześnie nazywa tę część Kantowskiej nauki najsłabszą i „przynoszącą [jej autorowi - A. M.] najmniej zaszczytu" ${ }^{47}$. Wszelkie ujawnione przez Kanta sprzeczności - jak suponuje - są jedynie trudnościami, gdyż w każdym wypadku, stawiając tezę i antytezę na wadze, jej szale - pod wpływem ciężaru argumentów - przechylając się na jedną ze stron, nigdy się nie równoważąc.

Wartenbergowskiej krytyce metafizycznego paradygmatu Kanta towarzyszą prace nad autorskim projektem filozofii, będącej wysiłkiem wzniesienia własnej budowli pluralistyczno-dualistycznej metafizyki, w której pierwszoplanową rolę odgrywa postulat uznający mnogość wzajemnie oddziałujących na siebie substancji, postrzeganych w kategoriach bezprzestrzennych atomów jako ośrodków lub centrów sił ${ }^{48}$; metafizyki, której wartość przejawia się w próbie trojakiego określenia jej wartości i zadań. Filozof pisze

\footnotetext{
${ }^{45}$ M. Wartenberg, Obrona metafizyki..., s. 157.

${ }^{46}$ Tamże, s. 93.

${ }^{47}$ Tamże, s. 155. Zob. M. Wartenberg, Das Problem des Wickens und die monistische Weltanschauung mit besonderer Beziehung auf Lotze. Eine historisch-kritische Untersuchung zur Metaphysik, Harvard 1900, s. 149-151.

${ }^{48}$ Zob. B. Dembowski, Spór o metafizykę..., s. 18, 83-84.
} 
o bezwzględnej potrzebie i możności podjęcia kwestii metafizyki; w tym celu poszukuje argumentów w obronie jej naukowego statusu ${ }^{49}$. Zakłada, że zadaniem metafizyki jest rozbiór i analiza pojęć bezkrytycznie przyjmowanych w naukach szczegółowych oraz precyzyjne badanie zjawisk danych w doświadczeniu. Metafizyka powinna rozjaśniać istotę zjawisk świata materialnego (nauk szczegółowych) i świata duchowego, a więc zobowiązuje się sprostać zadaniu właściwego określenia zjawisk typowych dla obu światów; misją metafizyki jest również wyjaśnienie realnej istoty zjawisk danych $\mathrm{w}$ doświadczeniu; natomiast priorytetowym celem metafizyki powinno być wypracowanie poglądu na całość bytu pod względem jego istoty, to znaczy konieczność wyrobienia naukowo-systematycznego stanowiska, biorącego pod uwagę całość bytu w jego istocie ${ }^{50}$.

Formuła nowoczesnej, naukowej - poprzedzonej gruntowną analizą teoriopoznawczą - metafizyki Wartenberga, każe odrzucić zarówno racjonalistyczną metafizykę przedkantowską, jak i metafizyczną spekulację po Kancie, zaproponowaną przez Hegla i jego szkołę. Współczesna Wartenbergowi refleksja epistemologiczna docenia "prace takich wybitnych metafizyków, jak Rudolf Hermann Lotze, Max Wundt i Eduard von Hartmann" ${ }^{51}$. Prace wyróżnionych filozofów „wnikają głęboko w istotę poznania i ujawniają wielkiej doniosłości pogląd, że dawna metafizyka znajdowała się w błędzie, przypisując swym poznaniom apodyktyczną pewność, absolutne znaczenie po wszystkie czasy. Metafizyka [oparta na przypuszczeniu - A. M.] uświadamia sobie granice poznania; zdaje sobie sprawę z istnienia różnych stopni pewności poznania" ${ }^{2}$; uznawszy, że nasze poznanie wyznacza zmienna perspektywa granicy sugeruje, iż próżnym wysiłkiem jest próba określenia tej granicy w sposób a priori. Jedynie analizy - hipotetycznej, czerpiącej z doświadczenia - metafizyki trzeźwego sądu, pozwolą nakreślić linię demarkacyjną naszej wiedzy, sytuując poznającego bezpośrednio przed aktualną granicą możliwego poznania. W ten sposób wyznaczony zostaje bieżący horyzont wiedzy.

Historycy filozofii projekt Wartenberga oceniają niejednoznacznie. Poglądy autora Das Problem des Wirkens spotykają się zarówno z krytyką, jak i z uznaniem, bez większego wysiłku bowiem można przywołać opinie

\footnotetext{
${ }^{49}$ Zob. M. Wartenberg, Obrona metafizyki..., s. 20. Por. W. Bajor, Wartenberg Mścisław Wiktor, [w:] Powszechna Encyklopedia Filozofii, t. 9, Lublin 2008, s. 702-704.

${ }^{50}$ Zob. S. Mazierski, Koncepcja metafizyki hipotetycznej u M. Wartenberga..., s. 76.

${ }^{51}$ M. Wartenberg, Obrona metafizyki..., s. 137.

${ }^{52}$ Tamże.
} 
podważające Wartenbergowską argumentację na rzecz prawomocności naukowo-hipotetycznej metafizyki oraz liczne głosy poparcia i uznania, które padają pod adresem jego metafizycznego programu.

Negatywny osąd wypowiada uczeń Kazimierza Twardowskiego - logik i filozof nauki - Zygmunt Michał Zawirski (1882-1948), sugerując, że gdyby sfera pozazjawiskowa mogła, zgodnie z postulatami Wartenberga, zostać wyrażona danymi doświadczenia w ten sam sposób, co sfera zmysłowa, to byłaby z nią równoznaczna. Jednak tego, co nie jest zjawiskiem (np. substancja), nie da się wytłumaczyć w kategoriach tego, co zjawiskowe, a wiedza o tym pozwala podważyć słuszność Wartenbergowskiego stanowiska ${ }^{53}$.

Głos krytyczny wydaje także - badający metafizyczne podstawy filozofii przyrody - Bolesław Józef Gawecki (1889-1984), sugerując, że samo przyjęcie przez Wartenberga rzeczywistości transcendentnej nie jest równoznaczne $\mathrm{z}$ uznaniem metafizycznego założenia. W obszar metafizyki wkroczylibyśmy według Gaweckiego dopiero z chwilą postawienia hipotezy określającej i precyzującej naturę tego obszaru, przyznając mu materialne bądź duchowe właściwości.

Projekt Wartenberga wywołuje także krytyczną reakcję uwzględnionego wcześniej Stanisława Mazierskiego, wprowadzającego rozróżnienie pomiędzy metafizyką jako docierającą do pierwszych, transcendentalnych, co znaczy „stojących ponad wszelkimi kategoriami pojęć" ${ }^{54}$ a naukami szczegółowymi, korzystającymi z metodologii dowodzeń i prostych twierdzeń, mającymi wyjaśnić wyłącznie związki przyczynowe między zjawiskami. Mazierski sądzi, że Wartenberg konfrontuje dane doświadczenia z myślową konstrukcją, zapominając o różnicach dzielących empirię, z jakiej weryfikująco czerpie swoją wiedzę fizyk, i metafizykę, która opiera się na dowodzie nie-wprost i nie jest nauką empiryczną w znaczeniu fizyki.

Także w tekście Anny Hochfeldowej poświęconym myśli Adama Mahrburga czytamy, że w związku z interpretacją filozofii Kanta „sytuacja była nadzwyczaj niepomyślna, czego świadectwem są wystąpienia Wartenberga, który »bierze imię krytycyzmu nadaremno«; zajmuje stanowisko czysto przedkantowskie, powołuje się jedynie na »znane zboczenia dogmatyczne» Kanta i »każe Kantowi-dogmatykowi pobijać Kanta-krytyka dla większej

${ }^{53}$ S. Mazierski, Koncepcja metafizyki hipotetycznej u M. Wartenberga..., s. 111. Zob. Z. Zawirski, Metoda aksjomatyczna a przyrodoznawstwo, „Kwartalnik Filozoficzny”, t. 1 i 2, 1923.

${ }^{54}$ S. Mazierski, Koncepcja metafizyki hipotetycznej u M. Wartenberga..., s. 112. 
chwały metafizyki «" ${ }^{55}$. W innym miejscu tej samej pracy czytamy o Wartenbergu: „takie to kwiatki wykwitają na katedrze filozofii w Krakowie, oczywiście nie z nadmiaru nauki" ${ }^{56}$. Słowa te zostały wypowiedziane przez Adama Mahrburga w związku z krytyką Wartenbergowskiego przekonania o fizyku i chemiku, którzy rozpatrują atom w kategoriach rzeczywistości czysto transcendentnej ${ }^{57}$. Mahrburg, podważający wartość analiz Wartenberga i zarzucający mu dogmatyczną pochopność, przekonuje, że: „żadne prawo przyrody nie jest konieczne dla naszego umysłu, gdyż jest ono tylko skróconym opisem danego w doświadczeniu przebiegu zjawisk" ${ }^{58}$.

Jednocześnie wielu polskich historyków filozofii, filozofów i intelektualistów udziela tłumaczowi Uzasadnienia metafizyki moralności głosu poparcia. Czynią tak między innymi: Stefan Zachariasz Pawlicki i Profesorowie Warszawskiego Seminarium Metropolitalnego Stanisław Gall i Wincenty Giebartowski, którzy w 1902 roku, po bliższym zapoznaniu się z Kantowską teoria przyczynowości (1899), zwracają się do Wartenberga z życzeniem prowadzenia dalszych szeroko zakrojonych studiów nad Kantowską filozofią, zwłaszcza „metafizyką, bez której badania filozoficzne są jak człowiek bez głowy" ${ }^{59}$. Także Władysław Bednarowski przywołuje pozytywny osąd filozoficznych osiągnięć Wartenberga wydany przez Ericha Adickesa, zaliczanego często - podobnie jak sam Wartenberg - do grona realistycznych interpretatorów myśli Kanta ${ }^{60}$. Filozoficzny wysiłek Wartenberga pozytywnie ocenia Władysław Tatarkiewicz i Kazimierz Ajdukiewicz. O ile Tatarkiewicz nazywa Wartenberga filozoficznym maksymalistą, o tyle Kazimierz Ajdukiewicz nadaje Wartenbergowi miano myśliciela „o własnym obliczu, który nie ogranicza się do zajmowania się pracami przygotowawczymi na przedpolu filozofii, lecz ma odwagę atakować centralne i najgłębsze problematy filozoficzne"61. Ajdukiewicz wyznaje, że Wartenberg podejmuje najcenniejsze poglądy, jakie w obronie naukowej metafizyki kiedykolwiek

${ }^{55}$ A. Hochfeldowa, Adam Mahrburg, [w:] Polska myśl filozoficzna i społeczna, t. 2, red. B. Skarga, Warszawa 1975, s. 165.

${ }_{56}$ Tamże, s. 183.

${ }^{57}$ Zob. tamże. Zob. A. Mahrburg, W sprawie naukowości metafizyki, [w:] Pisma filozoficzne, t. 2, Warszawa 1914, s. 234.

${ }^{58}$ A. Mahrburg, W sprawie naukowości metafizyki, [w:] Pisma filozoficzne, t. 2, s. 151.

${ }^{59}$ S. Gall, W. Giebartowski, Notatki bibliograficzne, 1902/1909, s. 126-127.

${ }^{60}$ W. Bednarowski, Mścisław Wartenberg, [w:] „Przegląd Filozoficzny” XLI, Warszawa 1938, s. 346.

${ }^{61}$ K. Ajdukiewicz, Mścisław Wartenberg..., s. 183. 
wypowiedziano $^{62}$; metafizyka Wartenberga, to nieapodyktyczna metafizyka środka, budowana na przełomie wieków jako odpowiedź na dwa skrajne stanowiska: metafizykę dogmatyczną, spekulatywną, żądającą absolutnej pewności oraz - odrzucający metafizykę - pozytywizm.

Ajdukiewicz - nazywając Wartenberga człowiekiem niezwykle skromnym i bezinteresownym, kochającym piękno i całą duszą oddanym pracy naukowej - przewiduje, że „przyszły historyk filozofii przyzna [mu - A. M.] na terenie polskiej myśli filozoficznej, pozycję analogiczną do tej, jaką w filozofii niemieckiej zajmuje, wysoce ceniony przez Wartenberga, Eduard von Hartmann"63.

Wybitny żninianin, oddany tropieniu sprzeczności i wszelkich niekonsekwencji Kantowskiego transcendentalizmu, zapisuje się w historii polskiej myśli filozoficznej jako stojący na straży metafizyki, krytyk skrajnie fenomenalistycznych i radykalnie apriorycznych założeń w koncepcji Królewieckiego myśliciela ${ }^{64}$. Poddając w wątpliwość wybrane założenia Krytyki czystego rozumu, wolny zarówno od koncepcji materialistycznych, naiwnej postaci realizmu, jak i idealistycznej spekulacji, projektuje własny program filozofii metafizycznej współbrzmiący z przesłankami metafizycznego kierunku w neokantyzmie. Jego myśl - inspirowana żywą polemiką z tezami Kantowskiego krytycyzmu, myślą pozytywistyczną oraz naukowymi teoriami przełomu XIX i XX wieku - staje się zogniskowanym na istocie esencjalizmem, oddziałującym zarówno na sposób rozumienia kwestii teoriopoznawczych, jak i na samą metafizykę, która nabywa cech teorii hipotetyczno-indukcyjnej.

\section{Bibliografia}

Ajdukiewicz K., Mścisław Wartenberg, „Ruch Filozoficzny” 1938/14.

Bajor W., Wartenberg Mścisław Wiktor, [w:] Powszechna encyklopedia filozofii, t. 9, Lublin 2008, s. 702-704.

Bednarowski W., Mścisław Wartenberg, „Przegląd Filozoficzny” XLI, Warszawa 1938.

Borzym S., Panorama polskiej myśli filozoficznej, Warszawa 1993.

\footnotetext{
${ }^{62}$ Tamże, s. 181.

${ }^{63}$ Tamże, s. 183.

${ }^{64}$ Zob. Słownik filozofów polskich, red. B. Andrzejewski, R. Kozłowski, Poznań 1999, s. 203-204.
} 
Dembowski B., Spór o metafizykę. Główne poglady na metafizykę w Polsce na przetomie XIX i XX w., Warszawa 1969.

Hochfeldowa A., Adam Mahrburg, [w:] Polska myśl filozoficzna i społeczna, t. 2, red. B. Skarga, Warszawa 1975.

Kant I., Krytyka czystego rozumu, przeł. R. Ingarden, Kęty 2001.

Kant I., Prolegomena do wszelkiej przyszłej metafizyki, która będzie mogła wystąić jako nauka, przeł. A. Banaszkiewicz, Kraków 2005.

Mahrburg A., W sprawie naukowości metafizyki, [w:] Pisma filozoficzne, t. 2, Warszawa 1914.

Mazierski S., Koncepcja metafizyki hipotetycznej u M. Wartenberga, „Collectanea Theologica. Societatis Theologorum Polonae Cura Edita” XXIV, Warszawa 1953.

Noras A., Kant a neokantyzm badeński i marburski, Katowice 2005, s. 17-100.

Słownik filozofów polskich, red. B. Andrzejewski, R. Kozłowski, Poznań 1999.

Wartenberg M., Das Problem des Wickens und die monistische Weltanschauung mit besonderer Beziehung auf Lotze. Eine historisch-kritische Untersuchung zur Metaphysik, Harvard 1900.

Wartenberg M., Kants Theorie der Kausalität mit besonderer Berücksichtigung der Grundprinzipien seiner Theorie der Erfahrung. Ein historisch-kritische Untersuchung zur Erkenntnistheorie, Jena 1898.

Wartenberg M., Obrona metafizyki. Krytyczny wstęp do metafizyki, Kraków 1902.

Wartenberg M., O kantowskiej krytyce praktycznego rozumu i jej stosunku do krytyki czystego rozumu, Lwów 1911.

Zawirski Z., Metoda aksjomatyczna a przyrodoznawstwo, „Kwartalnik Filozoficzny", t. 1 i 2, 1923.

Źródła internetowe:

Gall S., Giebartowski W., Notatki bibliograficzne, 1902/9. [www.ultramontes.pl/Metafizyka.htm]

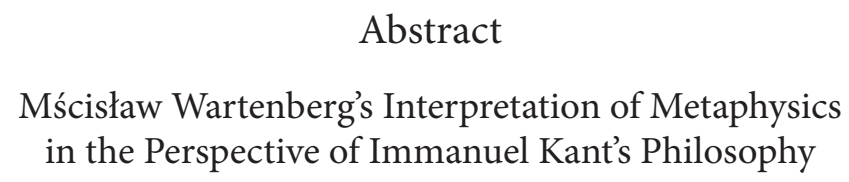

Philosopher and mathematician Mścisław Wiktor Wartenberg (1868-1938), belongs to circles of experts of Immanuel Kant's thought. How writes Wanda Bajor, the Thorough analysis of the Kantian philosophy gained him the acknowledgement in Poland and with the foreign lands. He tried to show that nor the idealism, nor the phenomenalism will lie, and a consequence of Kantianism is the realism. The critical interest with Kantian dualistic partition on this, what wonderful and 
is, what noumenal, Polish thinker of the turn of the century translates on the author's program of philosophy, wherein - asking after the possibility and the need of metaphysics - he undertakes attempt of the qualification of her status. Accordingly reaches for elaborate by Kant the definition of the metaphysics as the critical science about limits of recognition, throwing away simultaneously her primitive, speculative perception relevantly of the science treating about the transcendental world of themselves things in himself. Seeking arguments in defence of metaphysics, Wartenberg marks her high in the system of skills real, going deeply results of detailed sciences. He supposes, that all metaphysical considerations should be preceded by the thorough epistemological analysis, determining terminus a quo of metaphysical considerations. In the article I describe inspired with the transcendental Kant's thought, project of Wartenberg's philosophy whose the interpretation determines - dedicated to Adam Mironowski - the research work Obrona metafizyki. Krytyczny wstęp do metafizyki (1902).

Key words: Wartenberg, Kant, Neo-Kantianism, metaphysics, hypothetical metaphysics, transcendentalism 